Andrews, Manchester and Chicago. He was a vice-president of the Royal Society in 1939 and president of the Physical Society of London during 1941-44. He was created a Knight Commander of the British Empire in 1942.

G. B. B. M. Sutherlano

\section{Prof. B. C. P. Jansen}

Barend Coenraad Petrus Jansen was born on April 1, 1884, in the old Dutch town of Zwolle. At the age of twenty he entered the University of Amsterdam as a student of chemistry. He passed his final examination in 1909 and in the same year became assistant to the newly appointed professor of physiology in that University, G. van Rijnberk. In the stimulating scientific atmosphere, created by the young professor in the centuriesold building-in which the Physiological Laboratory is still housed to-day-Jansen took his first steps in biochemistry. The subjects he investigated were mainly related to digestion in the intestinal tract and the metabolism of the amino-acids. Outstanding was his discevery of the synthesis of urea from amino-acids in the mammalian liver in vitro, published in 1915. But before this work had been performed, namely, on July 10, 1912, Jansen had already obtained the doctorate of chemistry of the University of Utrecht, while in 1913 he had been admitted as privaat-docent in Physiological Chemistry at the University of Amsterdam.

Jansen's first period at this University came to an end in 1917, when he moved to Batavia (now Djakarta) in Java, then the capital of the Dutch East Indies. Here he was soon appointed head of the Department of Pharmacy and Chemistry of the Medical Laboratory, the institute in which the epoch-making researches of C. Eijkman and G. Grijns on polyneuritis gallinarum and human beriberi had been performed. The new building erected for this department according to Jansen's design was to be a model for well-equipped research institutions in the tropics.

In $1927 \mathrm{Jansen}$ was also appointed professor of chemistry in the newly founded Medical School in Batavia. But in this year his sojourn in the tropics was already running to its close. For in 1928 he was to return home as professor of physiological chemistry in the University of Amsterdam.

Human nutrition in the tropics, the field of research Jansen entered on his arrival in Java, suited his natural disposition extremely well : he was always most pleased if his results appeared applicable for the immediate benefit of mankind. Indeed his achievements, such as those on the iodine content of potable water in various regions or on the nutritional value of vegetable proteins, were of the highest importance for the health of the indigenous population. But also his greatest achievement of general scientific importance, which gave him world-wide fame, the isolation of pure crystalline vitamin $\mathrm{B}_{1}$ from huge amounts of rice-polishings, was initiated by his wish to provide an easily applicable weapon in the fight against beriberi.

In the autumn of 1928 Jansen returned to his old environments, the Physiological Laboratory in Amsterdam. After some extension and alteration the building provided sufficient room for provisionally accommodating a laboratory for physiological chemistry as well. The execution of plans for a new building was prevented first by the economic depression of the 'thirties, then by the outbreak of the Second World War. But, nevertheless, Jansen's laboratory soon became a centre of nutrition research in the Netherlands, the more so after he had also become director of the Nederlands Instituut voor Volksvoeding (Netherlands Institute for the Nutrition of the People) which was thereupon incorporated in his laboratory.

His devotion to the improvement of human nutrition was one of the chief causes of the rapid diffusion of the modern views on nutrition among the Dutch people. Under his direction many young physicians and chemists were trained in nutrition research; his lectures for the students of medicine generated numerous propagandists for better nutritional habits. Thus for many years he was the leading man in the field of nutrition in his country and one of the prominent specialists in the world. He was decorated by the Queen, he was a member of the Royal Netherlands Academy of Sciences and doctor honoris causa of the Sorbonne in Paris.

In his happy family life Jansen found a full understanding of the significance of his work; two of his three children (one daughter and two sons) worked for their theses under their father's guidance and received their doctor's certificate from his hands.

In 1954 Jansen reached the age of seventy, which obliged him to resign as professor. This did not mean that his activities suddenly came to an end, But gradually his health declined and he died on October 18, 1962, in his seventy-ninth year. His numerous friends, colleagues and pupils will always remember him as one of the noblest men they have ever met.

\section{H. G. K. WEStentrink}

\section{Dr. K. W. Luckhurst}

Kenneth Wilifam Luckhurst, who died on September 19, aged fifty-eight, was for twenty-five years secretary of the Royal Society of Arts and of the Faculty of Royal Designers for Industry. He was educated at the City of London School, and at Cambridge, where he read classics as a scholar of Emmanuel College. The early part of his career was spent in teaching, first at King's School, Canterbury, and then at the University of Edinburgh, where he was lecturer in Greek. In 1935 he was appointed assistant secretary of the Royal Society of Arts, and became secretary two years later. During the Second World War he served in the (Royal) Army Education Corps.

From the beginning of his secretaryship it was apparent that Luckhurst's own wide interests and clear, orderly mind were well suited to the varied and predominantly practical work of the Society for the Encouragement of Arts, Manufactures and Commerce. Holding its traditions in the highest regard, he also recognized how much of its strength derived from adaptability and a continuing sense of usefulness in the existing world. This understanding, and a gift for lucid exposition, informed his major published work, the History of the Society, written in collaboration with Derek Hudson to mark its bicentenary in 1954. Luckhurst afterwards expanded the earlier portion of his contributions into a doctorial thesis, which provides a valuable source of reference for the pioneering experiments in agriculture and chemistry fostered by the Society of Arts. Valuable in another connexion were his Cantor Lectures on the Great Exhibition of 1851, given in the year of the Festival of Britain, and his book The Story of Exhibitions, in which again he demonstrated the force of the Society's example.

The war years apart, the period of Luckhurst's administration was notably beneficial for the Society: membership and revenues more than doubled, additional premises were acquired, its activities, especially those on behalf of industrial design and commercial oducation, were given fresh impetus, and its reputation as a disinterested source of knowledge enhanced. In this last regard much depended on Luckhurst's judgment in organizing, each year, a lecture programme both representative of important developments in the sciences and useful arts, and providing interest and enjoyment for widely different audiences. Judicious attention to the details of each meeting enabled a long succession of visiting speakers to give of their best. $\mathrm{He}$ himself, pleasant and unhurried whatever his preoceupations, was 
always prepared to add to them-whether by stimulating a colleague, representing the Society on a committee or at a function, or undertaking an arduous journey overseas. He made three visits to North America to extend the Society's membership there, with the happiest results. Many Follows will remember him especially well as their delighted guide in informal tours of the Society's house.

Very little came amiss to Luckhurst, unless it was hearing disparagement of other people, or the sense of an opportunity incompletely realized. He created his own pattern of unobtrusive service, not easily copied.

\section{J. S. SKIDMORE}

\section{Dr. H. Banister}

Harry Banister, who died on January 19, in his eighty-first year, was appointed University lecturer in experimental psychology at Cambridge in 1926 and played a very active part in the affairs of the Psychological Laboratory for more than twenty years. Trained in physies, Banister brought to experimental psychology a great deal of good sense and a notable capacity for hard work. In his modest and sensible way, he did much to disarm suspicion of psychology in the University and to promote its teaching as an experimental discipline.

Banister had strong interests in acoustics, and his bestknown work was on the localization of sound. He took issue with C. S. Myers, who had claimed, in opposition to Lord Rayleigh, that binaural phase differences owe their effect mainly to binaural intensity differences. On the basis of some admirable experiments, Banister concluded that the principal cue for localization is the time-interval between the arrival of the sound-waves at the two ears. In spite of some modification, this remains the accepted view. Banister produced several other experimental papers on hearing, and the chapter on audition which he wrote for Murchison's Handbook of General Experimental
Psychology, published in 1934, for long remained a standard source.

Vision was another of Banister's interests, and he contributed a paper on retinal action time to a joint discussion held by the Physical and Optical Societies in 1932. He worked with Hartridge and Lythgoe on visual acuity and, together with J. M. Blackburn, reported an interesting correlation between inter-pupillary distance and skill in ball games. Banister also wrote a short text on statistical method which was widely used by undergraduate students of psychology between the two World Wars.

In his later years, Banister turned his attention inereasingly towards psychological medicine, and was extremely active in psychotherapeutic work. He took a lively interest in the psychological problems of the tuberculous patient, acting for some years as psychological adviser to the Papworth Village Settlement. He was also active in the Child Guidance Movement, being for a time director of the Cambridge Child Guidance Clinic. In all this work Banister enjoyed the full co-operation of his medical colleagues in Cambridge and farther afield. Although his interest in psychotherapy was essentially practical, he found time to publish a short book outlining recent theories in psychopathology and their application to problems of neurosis. He also published jointly two papers on the experimental induction of illusions of memory.

As a teacher, Banister is widely rememberod for his balanced approach to psychological issues and his firm reliance on the findings of experiment. He was an expositor of fact rather than theory, seldom allowing himself to be drawn into the psychological controversies of his time. Although this lack of the critical concern seemed to some a limitation, Banister was a much cleverer man than many of his pupils realized, his hesitations in regard to theory being due very largely to intellectual modesty. Had he been less diffident a man his contribution to psychology might well have been greater.

\section{O. L. ZANGWILI}

\section{NEWS and VIEWS}

\section{"World of Opportunity": the New Scientist}

IT is surprising to find that despite the widesproad attention directed to the United Nations conference last February on the application of science and technology for the benefit of the less-developed areas, the admirable issue "World of Opportunity" of the New Scientist of February 14 still appears to remain the only one in which that conference has been at all adequately handled by British periodicals. This comparative neglect, in spite of copious literature distributed by the Department of Scientific and Industrial Research, in no way detracts from the excellence of the issue of the New Scientist which is as welcome for its enterprise as for its intrinsic and timely merit. Bosides messages from the president of the conference, Prof. M. S. Thacker (of whom a profile is also included in the issue), and a message from Sir William Slater, leader of the British delogation, there are special articles by Dr. R. Revelle, science adviser to the secretary of the U.S. Department of the Interior, describing the Mission to the Indus of a panel of American scientists who studied irrigation in West Pakistan, and by Roy Herbert on the aftermath of the conference. A selection of papers presented at the conference is reproduced. These are by Prof. P. M. S. Blackott, on planning for science and technology in emergent countries; by Dr. S. H. Crowdy, on "Are Ploughs Obsolete ?"; by F. G. Lamont, on the genesis of a chemieal industry; and by G. Swaine, on fighting the plague of the army worm in East Africa.

\section{The Royal Irish Academy, Dublin}

At a meeting of the Royal Irish Academy in Dublin on March 16, Prof. J. L. Synge, director of the School of Theoretical Physics in the Dublin Institute for Advanced Studies, was elected president for the third year in succession. The following officers were elected: Prof. B. O Cuiv, secretary of the Academy and secretary for Irish Studies; Prof. J. J. Tierney, secretary of the Polite Literature and Antiquities Committee; Prof. P. J. Nolan, secretary of the Scionce Committee; Dr. V. C. Barry, treasurer; and Dr. J. St. P. Cowell, executive secretary. Dr. G. W. P. Dawson, Prof. M. A. Ellison, Prof. H. Halberstam, Prof. T. Jones Hughes, Dr. G. MacNiocaill, Prof. T. Murphy, and Dr. L. S. O'Raifeartaigh were elected members of the Academy.

\section{Computation at Manchester:}

Prof. S. Gill

Dr. Standey GrLl has been appointed to a nowly created (part-time) chair in computation in the Faculty of Technology at the University of Manchester and the Manchester College of Science and Technology. Dr. Gill was educated at Worthing High School and entered St. John's College, Cambridge, with a State scholarship and a major scholarship in 1942. He was successful in the Mathematics Tripos in 1945. In 1946 he accepted a temporary appointment at the National Physical Laboratory where he was engaged in scientific computing and in the design of $A C E$, one of the early computers designed there. He returned to Cambridge in 1948 and was 